\title{
Using $\mathrm{O}_{2}$ to study the relationships between soil $\mathrm{CO}_{2}$ efflux and soil respiration
}

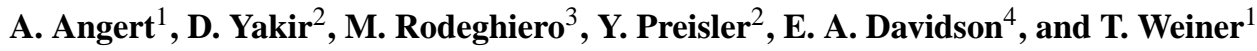 \\ ${ }^{1}$ The Institute of Earth Sciences, The Hebrew University of Jerusalem, Givat-Ram, Jerusalem 91904, Israel \\ ${ }^{2}$ Department of Earth and Planetary Sciences, Weizmann Institute of Science, Rehovot 76100, Israel \\ ${ }^{3}$ Sustainable Agro-ecosystems and Bioresources Department, IASMA Research and Innovation Centre, Fondazione Edmund \\ Mach, Via E. Mach 1, 38010 San Michele all'Adige (TN), Italy \\ ${ }^{4}$ Appalachian Laboratory, University of Maryland Center for Environmental Science, 301 Braddock Road, Frostburg, MD \\ 21532, USA
}

Correspondence to: A. Angert (angert@gmail.com)

Received: 17 April 2014 - Published in Biogeosciences Discuss.: 7 August 2014

Revised: 9 March 2015 - Accepted: 22 March 2015 - Published: 7 April 2015

\begin{abstract}
Soil respiration is the sum of respiration processes in the soil and is a major flux in the global carbon cycle. It is usually assumed that the $\mathrm{CO}_{2}$ efflux is equal to the soil respiration rate. Here we challenge this assumption by combining measurements of $\mathrm{CO}_{2}$ with high-precision measurements of $\mathrm{O}_{2}$. These measurements were conducted on different ecosystems and soil types and included measurements of air samples taken from the soil profile of three Mediterranean sites: a temperate forest and two alpine forests. Rootfree soils from the alpine sites were also incubated in the lab. We found that the ratio between the $\mathrm{CO}_{2}$ efflux and the $\mathrm{O}_{2}$ influx (defined as apparent respiratory quotient, ARQ) was in the range of 0.14 to 1.23 and considerably deviated from the value of $0.9 \pm 0.1$ expected from the elemental composition of average plants and soil organic matter. At the Mediterranean sites, these deviations are explained as a result of $\mathrm{CO}_{2}$ dissolution in the soil water and transformation to bicarbonate ions in these high-pH soils, as well as by carbonate mineral dissolution and precipitation processes. Thus, a correct estimate of the short-term, chamber-based biological respiratory flux in such soils can only be made by dividing the measured soil $\mathrm{CO}_{2}$ efflux by the average (efflux-weighted) soil profile ARQ. Applying this approach to a semiarid pine forest resulted in an estimated short-term biological respiration rate that is 3.8 times higher than the chamber-measured surface $\mathrm{CO}_{2}$. The ARQ values often observed in the more acidic soils were unexpectedly low $(<0.7)$. These values probably result from the oxidation of reduced iron, which has been
\end{abstract}

formed previously during times of high soil moisture and local anaerobic conditions inside soil aggregates. The results reported here provide direct quantitative evidence of a large temporal decoupling between soil-gas exchange fluxes and biological soil respiration.

\section{Introduction}

Respiration in soils is a major flux in the global carbon cycle, and contributes $\sim 100 \mathrm{Pg} \mathrm{Cyr}^{-1}$ to the atmosphere (BondLamberty and Thomson, 2010). As a result, this process has attracted much attention in recent decades (Davidson et al., 1998; Raich and Potter, 1995; Raich and Schlesinger, 1992; Vargas et al., 2011). Soil respiration is defined as the sum of heterotrophic respiration by soil microorganisms, mostly bacteria and fungi, and autotrophic respiration by living roots. It is usually estimated by measuring the $\mathrm{CO}_{2}$ efflux from the soil to a chamber placed above it (Davidson et al., 2002) or modeled on the basis of the $\mathrm{CO}_{2}$ concentration gradients in the soil profile (Davidson and Trumbore, 1995). Hence, the basic assumption is that the $\mathrm{CO}_{2}$ efflux is equal to the soil respiration. However, the $\mathrm{CO}_{2}$ efflux is not necessarily an ideal measure of the respiration rate for the following reasons.

First, instead of diffusing through the soil surface, a considerable fraction of the respired $\mathrm{CO}_{2}$ can be dissolved in the soil water, transported in the hydrological system, or take 
part in reactions of the carbonate system:

$\mathrm{CO}_{2}(\mathrm{~g}) \Leftrightarrow \mathrm{CO}_{2}(\mathrm{aq})+\mathrm{H}_{2} \mathrm{O} \Leftrightarrow \mathrm{H}_{2} \mathrm{CO}_{3} \Leftrightarrow \mathrm{HCO}_{3}^{-}+\mathrm{H}^{+} \Leftrightarrow \mathrm{CO}_{3}^{-2}+2 \mathrm{H}^{+}$.

In a calcareous soil with a $\mathrm{pH}$ of $\sim 8$, most of the carbon in the soil solution is in the form of bicarbonate $\left(\mathrm{HCO}_{3}^{-}\right)$. Using the carbonate system equilibrium relationships (Stumm and Morgan, 2012), it can be shown that in such a $\mathrm{pH}$ range the storage capacity of dissolved inorganic carbon (mainly bicarbonate) in soil water is considerable. For instance, we calculated - given the carbonate system constants (Stumm and Morgan, 2012) - that for a soil porosity of $50 \%$, which is $50 \%$ water-filled pores, a soil $p \mathrm{CO}_{2}$ of $10000 \mathrm{ppm}(1 \%)$, and a soil $\mathrm{pH}$ of $\sim 8$, the soil carbon storage capacity would

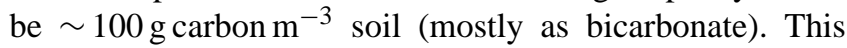
DIC (dissolved inorganic carbon) storage capacity is large in comparison to typical soil respiration rates, which are on the order of $\sim 2 \mathrm{~g} \mathrm{C} \mathrm{m}^{-2} \mathrm{~d}^{-1}$. This large storage capacity is particularly important when water is replaced by rain, irrigation, or any other water supply process. In addition, some $\mathrm{CO}_{2}$ will also be stored in gas phase in the soil pores. However, with the same soil parameter values as above, the gas phase storage will be only on the order of $1 \mathrm{~g}$. Hence, in calcareous soils the gas phase storage is negligible in comparison to the storage of dissolved inorganic carbon, unless large cavities exist below the soil.

Second, in addition to the DIC storage, in calcareous soils the $\mathrm{CO}_{2}$ can also be consumed in a calcium carbonate dissolution reaction,

$\mathrm{CaCO}_{3}+\mathrm{H}_{2} \mathrm{CO}_{3} \Leftrightarrow \mathrm{Ca}^{2+}+2 \mathrm{HCO}_{3}^{-}$,

or released in the reverse reaction. Such processes have been shown to influence the temporal variation in the soil $\mathrm{CO}_{2}$ efflux and to make it different than the biological process of respiration (Benavente et al., 2010; Cuezva et al., 2011; Emmerich, 2003; Eshel et al., 2007; Hastings et al., 2005; Kowalski et al., 2008; Roland et al., 2013; Schlesinger et al., 2009; Serrano-Ortiz et al., 2010; Tamir et al., 2011; Ma et al., 2013; Stevenson and Verburg, 2006; Wang et al., 2014).

Third, processes within roots may also cause the $\mathrm{CO}_{2}$ efflux to be different from the actual respiration rate. For example, the $\mathrm{CO}_{2}$ respired by roots can be dissolved in the xylem water and carried upward in the transpiration stream (Aubrey and Teskey, 2009; Bloemen et al., 2012).

The measurement of the $\mathrm{O}_{2}$ uptake rate is an alternative approach to measure respiration, which is routinely applied in studies of aquatic systems. However, making such measurements in the air phase, and especially under field conditions, is challenging since the atmospheric background of $\mathrm{O}_{2}$ is more than 500 times larger than that of $\mathrm{CO}_{2}(20.95$ vs. $0.04 \%$ ). Recently, Angert and Sherer (2011) have demonstrated that the combined measurement of $\mathrm{O}_{2}$ uptake in addition to the $\mathrm{CO}_{2}$ efflux can be used to isolate the biological respiration flux in a tree stem. This approach is based on the lower solubility of $\mathrm{O}_{2}$ in water (28 times lower than that of
$\mathrm{CO}_{2}$ at $20^{\circ} \mathrm{C}$ ) and also on the fact that $\mathrm{O}_{2}$, in contrast to $\mathrm{CO}_{2}$, does not form additional chemical species by reacting with water. Thus, the $\mathrm{O}_{2}$ influx may be a better measure of respiration than the widely used $\mathrm{CO}_{2}$ efflux, as was also suggested previously for plant respiration measurements in the lab (Amthor et al., 2001; Davey et al., 2004).

The ratio between the soil $\mathrm{CO}_{2}$ efflux to $\mathrm{O}_{2}$ influx has seldom been studied. Values of $0.59-0.78$ were reported (Severinghaus, 1995) for lab incubation of "Biosphere 2" soils, which may have resulted from carbonate reactions during the incubation. However, since the alkalinity or $\mathrm{pH}$ was not measured, this could not be confirmed. Other soils incubated in that study in an open system with no $\mathrm{CO}_{2}$ buildup gave values of 0.83-0.95 and of 0.84 for an in situ soil-chamber experiment. Seibt et al. (2004) reported values in a forest soil chamber which correspond to the respiratory quotient (RQ) of 1.5 (and to 1.06 after removing one data point which was considered to be an outlier): this is higher than the 0.90 value reported recently for a soil chamber in a forest in Japan (Ishidoya et al., 2013). An average value of 1.0 for soil profiles were found in the Amazonian tropical forest in Peru (Angert et al., 2012).

Here we have used high-accuracy measurements of $\mathrm{O}_{2}$ concentrations to study the relationships between soil $\mathrm{CO}_{2}$ efflux and soil respiration in well-drained soils and to determine how $\mathrm{O}_{2}$ measurements can help to better quantify and understand soil respiration. To make our conclusions more general, the study was conducted in different ecosystems, in calcareous and noncalcareous soils, and over a wide range of soil $\mathrm{CO}_{2}$ and $\mathrm{O}_{2}$ concentrations. Finally, we demonstrate how $\mathrm{O}_{2}$ measurements can be used to correct $\mathrm{CO}_{2}$ measurements for estimating soil respiration flux.

\subsection{Expected relationships between $\mathrm{O}_{2}$ and $\mathrm{CO}_{2}$ in soils}

In a one-dimensional model, the change with time of the concentration $(C)$ of a gas in soil is related to the concentration gradient with depth $(z)$, the gas diffusivity in the soil $(D)$ and the rate of net $\mathrm{CO}_{2}$ production $(P)$. This net rate of $\mathrm{CO}_{2}$ production integrates the effects of respiration and of $\mathrm{CO}_{2}$ storage and release discussed above. The one-dimensional model is summarized by the diffusion-production equation (Jury et al., 1991; Stern et al., 1999):

$\frac{\partial C}{\partial t}=D \frac{\partial^{2} C}{\partial z^{2}}-P(z)$.

This reaction-diffusion model ignores advection, which can be important in some cases (Maier et al., 2012). For this reason we have conducted all of our experiments under low wind speed $\left(<4 \mathrm{~m} \mathrm{~s}^{-1}\right)$ conditions. For solving Eq. (1), we can for instance assume that the $\mathrm{CO}_{2}$ production rate decreases exponentially with depth such that $P(z)=$ $P^{\prime} \exp \left(-z / z_{\mathrm{e}}\right)$, where $P^{\prime}$ is the rate of $\mathrm{CO}_{2}$ production at the soil surface and $z_{\mathrm{e}}$ is the depth at which the rate equals $P^{\prime} / e$. 
Then the steady-state solution for the concentration gradient between the soil and the atmosphere $(z=0)$ becomes

$C(z)-\mathrm{C}_{\mathrm{atm}}=\left(P^{\prime} \cdot z_{e}^{2} / D\right)\left(1-\exp \left(-z / z_{e}\right)\right)$

(Hesterberg and Siegenthaler, 1991).

We represent the difference between $C(z)$ and $\mathrm{C}_{\text {atm }}$ as $\Delta$ and indicate $\mathrm{O}_{2}$ and $\mathrm{CO}_{2}$ with the subscripts "O" and " $\mathrm{C}$ " $\left(P_{\mathrm{O}}\right.$ takes negative values since $\mathrm{O}_{2}$ is consumed). Writing two equations, one for $\mathrm{CO}_{2}$ and one for $\mathrm{O}_{2}$, and dividing the first by the second yields

$\frac{P_{\mathrm{C}}}{P_{\mathrm{O}}}=\frac{D_{\mathrm{C}}}{D_{\mathrm{O}}} \frac{\Delta_{\mathrm{C}}}{\Delta_{\mathrm{O}}}$.

We will define the ratio between the soil $\mathrm{CO}_{2}$ efflux to $\mathrm{O}_{2}$ influx as the soil ARQ (apparent respiratory quotient), which is similar to the definition for tree stems (Angert et al., 2012; Angert and Sherer, 2011), so $A R Q=-P_{C} / P_{O}$. If only respiration drives the soil ARQ, then it will be equal to the RQ or to the inverse of the oxidative ratio (OR, which is $1 / \mathrm{RQ})$.

The $D_{\mathrm{C}} / D_{\mathrm{O}}$ term in Eq. (3) can be calculated from the relationship between the diffusivity $(D)$ of a gas in soil and the diffusivity in air $\left(D_{0}\right)$ :

$D=Q \cdot D_{0}$,

where $Q$ is the relative effective diffusivity, that depends on the structure of the air-filled pore spaces (Millington and Shearer, 1971). Hence, we can assume that $Q$ is identical for $\mathrm{CO}_{2}$ and $\mathrm{O}_{2}$. As a result, the ratio $\left(D_{\mathrm{C}} / \mathrm{D}_{\mathrm{O}}\right)$ becomes equal to the ratio of $\mathrm{CO}_{2} / \mathrm{O}_{2}$ diffusivity in air, which is $0.76\left(0.138 \mathrm{~cm}^{2} \mathrm{~s}^{-1} / 0.182 \mathrm{~cm}^{2} \mathrm{~s}^{-1}\right.$ at STP (standard temperature and pressure) and is independent of temperature, since for different temperatures both diffusivity coefficients will change by the same factor (Massman, 1998). Thus, Eq. (3) becomes

$\mathrm{ARQ}=-0.76\left(\Delta_{\mathrm{C}} / \Delta_{\mathrm{O}}\right)$.

In addition, the soil ARQ can be calculated from measurements of $\mathrm{O}_{2}$ and $\mathrm{CO}_{2}$ concentrations in the soil. It can be shown by a numerical model that Eq. (7) is valid also when other respiration profiles are assumed.

Previous studies have estimated the OR (and hence the RQ) of biomass and soil organic material. The RQ of the following plant chemical classes was calculated (Randerson et al., 2006) as 0.88 for lignin, 0.95 for soluble phenolics, 1.0 for carbohydrates, 1.4 for organic acids, and 0.73 for lipids. In anaerobic respiration RQ $>>1$ since $\mathrm{CO}_{2}$ emission is uncoupled from $\mathrm{O}_{2}$ consumption. Nitrate assimilation by roots will make the RQ values increase above 1 since nitrate is used instead of $\mathrm{O}_{2}$ as an electron acceptor (Lambers et al., 2008). On average, and in steady state, the RQ of respiration related to the decomposition of soil organic matter must reflect the stoichiometric ratios found in the soil organic matter. Severinghaus (1995) calculated OR values from elemental abundance data; these values correspond to RQ values of 0.93 for average plant, 0.95 for wood, and 0.93 for soil humic acid and humins. The analysis of biomass by elemental composition and by the heat of combustion yielded similar OR values, which correspond to an RQ of 0.94-1.01 (Masiello et al., 2008). The corresponding RQ values found by ${ }^{13} \mathrm{C}$ nuclear magnetic resonance for soil (Hockaday et al., 2009) are $0.82-1.04$. These values agree well with the values estimated by Severinghaus (1995) by the incubation of various soils in steady-state chambers (and by one in situ flux measurement) that correspond to RQ values of $0.8-1.0$. Hence, if only respiration processes and diffusion drive the concentration gradients in the soil, the decrease in soil oxygen $\left(-\Delta_{O}\right)$ is expected to be equal to, or higher by up to $20 \%$ than, the increase in $\mathrm{CO}_{2}$ concentration gradient, corrected for the lower diffusivity $\left(0.76 \times \Delta_{\mathrm{C}}\right)$. However, if $\mathrm{CO}_{2}$ is removed by nonrespiratory processes, such as chemical processes in soil, or by dissolution and biological processes within the roots, or if the respiration substrate has a different RQ from the values cited above, then the $-\Delta_{\mathrm{O}}$ can be far from $0.76 \times \Delta_{\mathrm{C}}$ and the ARQ will be significantly different from $0.9 \pm 0.1$.

\section{Methods}

We aimed to provide observational information on the relationships between $\mathrm{CO}_{2}$ production and $\mathrm{O}_{2}$ consumption across a range of soils and seasons. This included soil depth profiles (to about $150 \mathrm{~cm}$ ) at three Mediterranean sites and single depth samplings at temperate and alpine sites. These observations were supplemented with laboratory incubations of some of the samples as well as analysis of the $\mathrm{CO}_{2}$ and $\mathrm{O}_{2}$ transport and consumption in sterilized-soil columns.

\subsection{In situ soil air sampling}

To study the $\mathrm{CO}_{2}-\mathrm{O}_{2}$ relationships in different conditions, we chose to sample soil air from six sites with different ecosystems (alpine broadleaf and needleleaf forests, temperate forest, orchard, and Mediterranean and semiarid pine forest), with calcareous and noncalcareous soils and with varying soils and respiration rates, which induce varying gradients in soil $\mathrm{CO}_{2}$ and $\mathrm{O}_{2}$. Soil air was sampled from stainless steel tubes closed at the bottom end, and perforated near the bottom. The soil air was sampled at the following six sites:

1. A citrus orchard located near Kefar-Vitkin, Israel $\left(32^{\circ} 23^{\prime} \mathrm{N}, 34^{\circ} 53^{\prime} \mathrm{E}\right)$. At this site, the soil is Calcic Vertisol (FAO classification) and changes gradually from clay in the top layers to calcareous sandy clay loam in the deeper ones. This site is irrigated every 2 weeks in summer. Samples were taken from depths of 30, 60, 90, 120, and $150 \mathrm{~cm}$, in duplicates. In September 1999, sampling started 10 days after the last irrigation, and in 
March 2000 it started 3 days after a rain event. Both samplings ended before the next rain or irrigation event.

2. Yatir forest site, a 45-year-old Aleppo pine (Pinus halepensis) plantation located on the northern edge of the Negev Desert, Israel $\left(31^{\circ} 20^{\prime} \mathrm{N}, 35^{\circ} 20^{\prime} \mathrm{E}\right.$; elevation $650 \mathrm{~m}$ ). The forest covers an area of $2800 \mathrm{ha}$ and lies on a Rendzic Leptosol soil (FAO classification, $79 \pm 45.7 \mathrm{~cm}$ deep), overlying chalk and limestone bedrock. The climate is hot (40-year average mean annual temperature is $\left.18^{\circ} \mathrm{C}\right)$ and dry (40-year average mean annual precipitation is $280 \mathrm{~mm}$ ). Monthly soil efflux measurements, soil moisture profiles, and the determination of soil characteristics have been routinely carried out at this site (Rotenberg and Yakir, 2010). Samples for ARQ measurements were taken during 2013, from depths of $30,60,90$, and $120 \mathrm{~cm}$.

3. A pine grove site located at the Hebrew University Givat Ram campus $\left(31^{\circ} 46^{\prime} \mathrm{N}, 35^{\circ} 12^{\prime} \mathrm{E}\right.$; elevation $\left.771 \mathrm{~m}\right)$ in Jerusalem, on the Judea hills. The climate is semihumid Mediterranean with a mean annual rainfall of $537 \mathrm{~mm}$ (1981-2010) and an average temperature of $16.8^{\circ} \mathrm{C}$. The soil type is Chromic Luvisol (FAO classification) which lies on a carbonate bedrock (Cenomenian dolomite). The vegetation is dominated by Pinus halepensis. Samples for ARQ measurements were taken from May 2012 to August 2013, at $40 \mathrm{~cm}$ depth.

4. A temperate forest site located on the Prospect Hill tract of Harvard Forest, near Petersham, Massachusetts USA $\left(42^{\circ} 32^{\prime} \mathrm{N}, 72^{\circ} 11^{\prime} \mathrm{W}\right)$ at $340 \mathrm{~m}$ elevation. The mean annual rainfall is $1050 \mathrm{~mm}$. This mixed hardwood forest is about 60 years old and is dominated by red oak (Quercus rubra L.) and red maple (Acer rubrum L.), with some stands of hemlock, white pine, and red pine. The sampling site was near the base of the eddy covariance flux tower (Barford et al., 2001). The soil is classified as Dystric Cambisol (FAO classification), the texture is sandy loam, and the soil is well drained. Samples were taken from $85 \mathrm{~cm}$ depth, and 10 replicates were taken at each sampling time to ensure sufficient replication necessary due to the small soil-air $\mathrm{O}_{2}$ gradient at this site. This resulted in standard error in the $\mathrm{O}_{2}$ concentration measurements of $\pm 0.02 \%$. Samples for ARQ measurements were taken in May and July 2001.

5. An alpine beech (Fagus sylvatica L.) forest in Italy $\left(46^{\circ} 03^{\prime} \mathrm{N}, 11^{\circ} 04^{\prime} \mathrm{E}\right)$, with a mean annual air temperature of $8.6^{\circ} \mathrm{C}$ and an average annual rainfall of $976 \mathrm{~mm}$. The soil is a Calcaric Cambisol (FAO classification). This site is described in detail in Rodeghiero and Cescatti (2005; appears there as S6). Soil air was sampled from $30 \mathrm{~cm}$ depth for the ARQ from one soil tube in June 2011 and from two soil tubes $\sim 3 \mathrm{~m}$ apart during September 2013.
6. An alpine Norway spruce (Picea abies (L.) Karsten) forest site in Italy $\left(46^{\circ} 02^{\prime} \mathrm{N}, 11^{\circ} 03^{\prime} \mathrm{E}\right)$, with a mean annual air temperature of $5.9^{\circ} \mathrm{C}$ and an average annual rainfall of $1015 \mathrm{~mm}$. The soil is a Calcaric Skeletic Cambisol (FAO classification). This site is described in detail by Rodeghiero and Cescatti (2005; appears there as S8). In September 2013 The soil air was sampled at $30 \mathrm{~cm}$ depth for the ARQ from three soil tubes, which were $\sim 3 \mathrm{~m}$ apart.

\subsection{Diffusion experiments in sterilized-soil columns}

To study the effects of soil chemistry and gas diffusion separately from biological effects, we conducted a set of experiments with sterilized-soil columns. The soil columns were prepared by filling a glass tube, $(8 \mathrm{~cm}$ long, $0.6 \mathrm{~cm}$ outer diameter, $0.4 \mathrm{~cm}$ internal diameter) with $2.0-2.4 \mathrm{~g}$ loose soil or sand. The soil samples were (1) Chromic Luvisols (FAO classification) with a clay content of $49 \%$ and a soil $\mathrm{pH}$ of 7.6, sampled at a site with natural vegetation and Mediterranean climate in the Judean Mountains $\left(31^{\circ} 42^{\prime} \mathrm{N}, 35^{\circ} 3^{\prime} \mathrm{E}\right)$; (2) a sample from site 5 , with a clay content of $42 \%$ and a soil $\mathrm{pH}$ of 7.3 ; (3) a sample from site 6 , with a clay content of $31 \%$ and a soil $\mathrm{pH}$ of 4.9; and (4) acid-washed sand (Merck), with a clay content of $0 \%$. The soils were sterilized by gamma radiation from a cesium-137 source for at least $5 \mathrm{~h}$. Overnight incubation of the gamma-treated soils showed no $\mathrm{CO}_{2}$ emission and no $\mathrm{O}_{2}$ consumption even after rewetting the soils, which indicates that the sterilization was successful.

Plugs made of alumina wool were inserted in both ends of the glass tube to keep the soil in place, while allowing air movement. The soil column was placed horizontally and connected to a $3.6 \mathrm{~mL}$ glass flask equipped with a Louwers ${ }^{\mathrm{TM}}$ O-ring high-vacuum valve. $\mathrm{CO}_{2}$ and $\mathrm{O}_{2}$ were set to either diffuse out of the flasks or into it by either (1) connecting a flask with $8700 \mathrm{ppm} \mathrm{CO}_{2}$ in $\mathrm{N}_{2}$ to one end of the soil column, while leaving the other end open to the outside air, or (2) connecting one side of the column to a flask with outside air and the other end of the soil column to $40 \mathrm{~mL}$ flasks filled with the above $\mathrm{CO}_{2}-\mathrm{N}_{2}$ mixture. Diffusion across the soil columns was allowed for 30-60 min before the flasks were closed and $\mathrm{CO}_{2}$ and $\mathrm{O}_{2}$ concentrations in the flask were then measured as indicated below. Based on the $\mathrm{O}_{2}$ concentrations in the flasks at the end of the experiments, we calculated the expected $\mathrm{CO}_{2}$ concentration, assuming that diffusion was the only process taking place and knowing the ratio between the diffusivities of these two gases ( 0.76 , see introduction). We note that the use of $\mathrm{CO}_{2}-\mathrm{N}_{2}$ mixtures in the experiments slightly changed the diffusivity ratios, compared to that of air, but the effect was considered to be within the uncertainty of the measurement ( $\sim 0.02$ in the diffusivity ratios) and was not considered in the calculations. 


\subsection{Soil incubation experiments}

To study the effects of heterotrophic respiration separately from the effects of root respiration and that of gas diffusion in the soil profile, we conducted incubation experiments. To this end, soils were sampled at the alpine sites in September 2013 and were incubated for $\sim 5-44 \mathrm{~h}$ in $60 \mathrm{~mL}$ glass flasks connected with Swagelok Ultra-Torr tee fittings to two $3.6 \mathrm{~mL}$ glass flasks equipped with Louwers ${ }^{\mathrm{TM}}$ high-vacuum valves. Before the incubation, the soils were sieved to $2 \mathrm{~mm}$ to remove roots, and repeated incubations were made with the same soils. Before the last incubation, sucrose $\left(50 \mu \mathrm{mol} \mathrm{g}{ }^{-1}\right.$ soil) was added to the soils. Soil moisture content and soil $\mathrm{pH}$ were measured, and the total dissolved inorganic carbon (DIC) in the soil solution was calculated based on these parameters and the $\mathrm{CO}_{2}$ concentration using the carbonate system constants and equations (Stumm and Morgan, 2012). The DIC values were used to calculate the "corrected ARQ", which accounts for the fraction of respired $\mathrm{CO}_{2}$ which is not in the gas phase.

\subsection{Gas analysis}

Samples of soil air were collected in pre-evacuated $\sim 3.6 \mathrm{~mL}$ glass flasks with Louwer ${ }^{\mathrm{TM}} \mathrm{O}$-ring high-vacuum valves. Before sampling, the dead volume in the tubing and flask necks was purged with soil air by a plastic syringe equipped with a three-way valve. Duplicate samples were taken at all sites, except at the Harvard forest site, where 10 replicates were taken (due to the close-to-ambient $\mathrm{O}_{2}$ concentrations). At sites 1 and 4, oxygen concentrations were calculated from $\delta\left(\mathrm{O}_{2} / \mathrm{Ar}\right)$ values that were measured on a Finnigan Delta plus mass spectrometer, assuming that, since argon is inert, its concentration is constant (Angert et al., 2001). The standard error in the $\mathrm{O}_{2}$ concentration measurements was $\pm 0.08 \%$ at site 1 and $0.02 \%$ at site 4 . The air used for $\mathrm{CO}_{2}$ measurements was collected in evacuated blood collection tubes (vacutainers ${ }^{\circledR}$ ) at site 1 , syringes at site 4 , and in the same flasks used for $\mathrm{O}_{2}$ at all other sites. At sites 1 and 4 , the $\mathrm{CO}_{2}$ concentration was measured in the laboratory with a LI-COR-6252 $\mathrm{CO}_{2}$ analyzer (LI-COR, Lincoln, NE, USA) by the method described in Davidson and Trumbore (1995) with a relative error of $\pm 5 \%$. For the other sites as well as for the diffusion and incubation experiment (see below), the $\mathrm{CO}_{2}$ and $\mathrm{O}_{2}$ concentrations were measured on an air circulating system similar to that described in Angert and Sherer (2011). The $\mathrm{O}_{2}$ concentration was measured by a fuel-cell-based $\mathrm{O}_{2}$ analyzer (Sable Systems FC-10) that was in the circulation loop. The analyzer $\left[\mathrm{O}_{2}\right]$ reading was corrected for the system's internal pressure and for dilution by water vapor. Water vapor concentrations and $\mathrm{CO}_{2}$ concentrations were determined by a Li-840A (LI-COR, Lincoln, NE, USA) infrared gas analyzer, through which the air flow in the circulating system passed before entering the oxygen analyzer. The ac- curacy and precision in $\left[\mathrm{O}_{2}\right]$ and $\left[\mathrm{CO}_{2}\right]$ determination by this method was $\pm 0.04 \%$ for both gases.

\section{Results}

The derived ARQ values were well beyond the range expected for steady-state respiration (both below and above this range). In temperate and alpine soils, we found values that were lower than expected despite the low $\mathrm{pH}$ values, which limit DIC storage.

\subsection{Soil depth profiles}

The results of soil air in situ measurements at the Mediterranean sites 1 and 2 are presented in Figs. 1 and 2. The decrease in oxygen $\left(-\Delta \mathrm{O}_{2}\right)$ was larger than the diffusioncorrected increase in carbon dioxide $\left(0.76 \Delta \mathrm{CO}_{2}\right)$ at site 2 in January, and the ARQ value was 0.68 at $30 \mathrm{~cm}$ depth and ranged between 0.14 to 0.22 at the $60-120 \mathrm{~cm}$ depth range. In April the $0.76 \Delta \mathrm{CO}_{2}$ value was closer to that of $-\Delta \mathrm{O}_{2}$ and the average ARQ value in the profile was 0.79 . In site 1 the ARQ values were as low as 0.29 on some dates (10 March, $150 \mathrm{~cm}$ depth) but were close to 1.0 , or above 1.0 (1.23, for the profile average on 12 September) on others.

\subsection{Single-point measurements}

At the third Mediterranean site (site 3), the decrease in oxygen $\left(-\Delta \mathrm{O}_{2}\right)$ was larger than the diffusion-corrected increase in carbon dioxide $\left(0.76 \Delta \mathrm{CO}_{2}\right)$ during some months and equal to it within the experimental uncertainty in other months (Fig. 3). The results from the temperate forest site (site 4 ) and alpine forest sites (sites 5 and 6 ) are presented in Table 1, which shows ARQ values ranging between 0.23 and 0.96.

It should be noted that our analysis is based on the assumption of soil air in steady state and that, due to low wind speeds $\left(<4 \mathrm{~m} \mathrm{~s}^{-1}\right)$ during the sampling, gas exchange was only by diffusion, so that advection could be ignored. In an extreme case, in which advection was dominating the gas exchange, the 0.76 factor in Eq. (7) should be omitted and the low range of our ARQ values would be 0.30 instead of 0.26 , which would not significantly affect our interpretation.

\subsection{Diffusion experiments}

The $\mathrm{CO}_{2}$ concentrations at the end of the diffusion experiments with acid-washed sand and gamma-sterilized alpine soils agreed well with the values calculated from the $\mathrm{O}_{2}$ concentration (based on relative rates of $\mathrm{O}_{2}$ and $\mathrm{CO}_{2}$ diffusion in air; Fig. 4). In contrast, the experiments with Mediterranean calcareous soils fell below the 1:1 line, indicating lower measured $\mathrm{CO}_{2}$ than that expected from diffusion processes alone (Fig. 4). 
Table 1. The $\left[\mathrm{CO}_{2}\right],\left[\mathrm{O}_{2}\right]$, and ARQ (average values of replicates) for in situ measurements in acidic and neutral soils in temperate and alpine forest sites (sites $4,5,6$ ). Apparent respiratory quotient (ARQ) values different from the $0.9 \pm 0.1$ expected for respiration (based on plant composition) were observed in these soils.

\begin{tabular}{lllrcrrc}
\hline Date & Site & Description & Soil pH & Depth $(\mathrm{cm})$ & $\mathrm{CO}_{2} \%$ & $\mathrm{O}_{2} \%$ & ARQ \\
\hline $30 / 05 / 2001$ & 4 & Temperate forest & 4.5 & 85 & 0.46 & 20.40 & $0.58 \pm 0.05$ \\
$31 / 07 / 2001$ & 4 & Temperate forest & 4.5 & 85 & 0.73 & 20.20 & $0.70 \pm 0.05$ \\
$07 / 06 / 2011$ & 5 & Alpine forest & 7.3 & 40 & 0.62 & 19.06 & $0.23 \pm 0.04$ \\
$09 / 09 / 2013$ & 5 & Alpine forest & 7.3 & 30 & 0.28 & 20.67 & $0.64 \pm 0.06$ \\
$09 / 09 / 2013$ & 6 & Alpine forest & 4.9 & 30 & 0.26 & 20.77 & $0.96 \pm 0.24$ \\
\hline
\end{tabular}
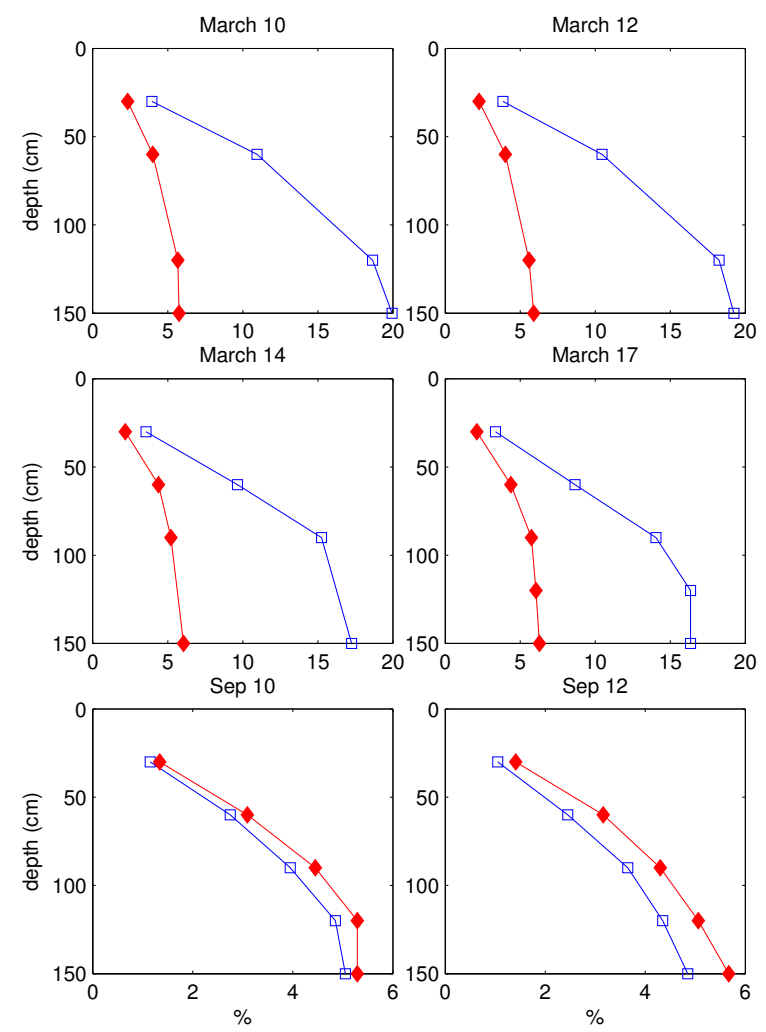

Figure 1. Temporal variations in depth profiles of $-\Delta \mathrm{O}_{2}$ (open blue squares, $\mathrm{O}_{2}$ decrease from ambient) and $0.76 \Delta \mathrm{CO}_{2}$ (red diamonds, $\mathrm{CO}_{2}$ increase above ambient corrected for lower gas diffusivity compared to $\mathrm{O}_{2}$ ) profiles in the soil of site 1 (citrus orchard). The March experiment started 3 days after a rain event, while the September experiment started 10 days after irrigation. Error bars are smaller than the markers.

\subsection{Soil incubation experiments}

The incubation experiment with alpine soils (Table 2) gave dissolution-corrected ARQ values ranging between 0.60 and 1.24 (0.54-0.92 uncorrected). The results indicate ARQ values decreasing with time since soil sampling from $\sim 0.9$ to $\sim 0.8$ and $\sim 0.8$ to $\sim 0.6$ in soil samples from the two depths of site 6 over about $140 \mathrm{~h}$ and from $\sim 0.9$ to $\sim 0.7$ in the site 5 sample over a similar period. This trend was reversed in
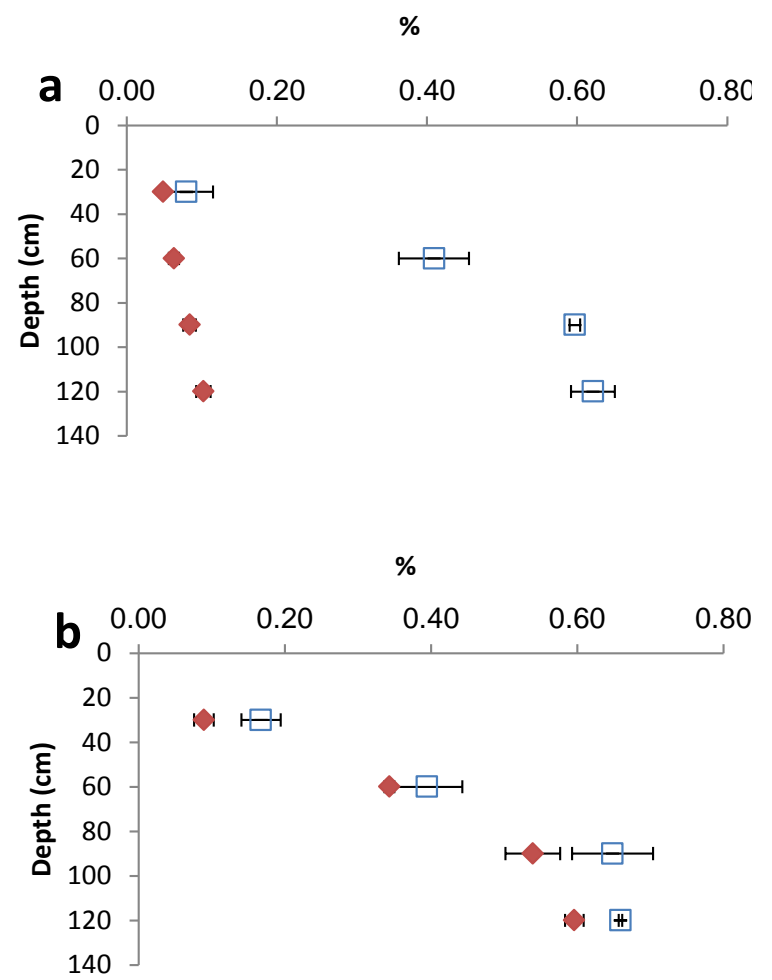

Figure 2. The $-\Delta \mathrm{O}_{2}$ (open blue squares, $\mathrm{O}_{2}$ decrease from ambient) and $0.76 \Delta \mathrm{CO}_{2}$ (red diamonds, $\mathrm{CO}_{2}$ increase above ambient corrected for lower gas diffusivity compared to $\mathrm{O}_{2}$ ) profiles in the soil of site 2 (semiarid pine forest) in January (a) and April (b). The values are in percent (same units as in Fig. 1, but note that the concentration changes here are lower by 1 order of magnitude than in Fig. 1). Some error bars are smaller than the markers.

later incubations when sucrose was added, with ARQ values of $0.74-1.24$.

\section{Discussion}

Based on the variations in the $\mathrm{CO}_{2} / \mathrm{O}_{2}$ concentration ratios in soil profiles, we demonstrated widespread temporal decoupling between soil-gas exchange fluxes and biological respiration. $\mathrm{CO}_{2}$ dissolution in soil water and abiotic inter- 


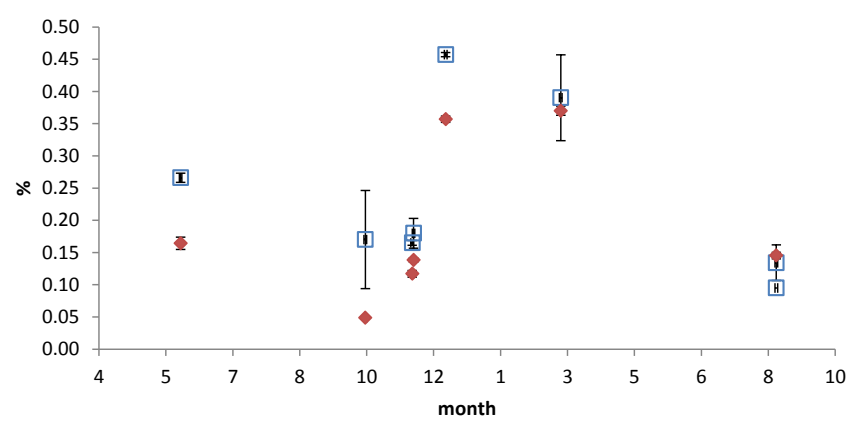

Figure 3. Temporal changes in $-\Delta \mathrm{O}_{2}$ (open blue squares, $\mathrm{O}_{2}$ decrease from ambient) and $0.76 \Delta \mathrm{CO}_{2}$ (red diamonds, $\mathrm{CO}_{2}$ increase above ambient corrected for lower gas diffusivity compared to $\mathrm{O}_{2}$ ) at the soil of site 3 (pine stand; $40 \mathrm{~cm}$ depth) from May 2012 to August 2013. Most error bars are smaller than the markers.

actions with the carbonate systems (calcareous soils) and oxidation of reduced iron (acidic soils) could explain most of this decoupling.

\subsection{Relationships between $\mathrm{CO}_{2}$ and soil respiration in calcareous soils}

The ARQ values measured at the Mediterranean calcareous soil sites (sites 1, 2, and 3; Figs. 1, 2, and 3) clearly exceeded the range expected for soil respiration (Hockaday et al., 2009; Masiello et al., 2008; Severinghaus, 1995), being well below and above 0.9. These deviations from the expected RQ values were evident at all three calcareous soil sites, despite 1 order of magnitude difference in soil $\mathrm{CO}_{2}$ concentrations. The low ARQ values can be explained if, in addition to respiration, the soil gases also react with the soil water. In addition to the processes of $\mathrm{CO}_{2}$ storage and transport in soil water, the dissolved $\mathrm{CO}_{2}$ can react with the bedrock-derived soil carbonate minerals.

Possible evidence of such reactions is represented by the high $\delta^{13} \mathrm{C}$ values of around $-14 \%$ observed in soil $\mathrm{CO}_{2}$ and DIC at site 2 (Carmi et al., 2013). These values are significantly higher than the $\delta^{13} \mathrm{C}$ values of -21 to $-23 \%$ observed in the forest trees (Klein et al., 2005) and may indicate that the dissolved $\mathrm{CO}_{2}$ and bicarbonate interact with bedrock carbonates (producing a $\delta^{13} \mathrm{C}$ value of soil $\mathrm{CO}_{2}$ in equilibrium with carbonate minerals of -8 to $-9 \%$ o). While the isotopes do not indicate net fluxes, they do indicate that the rate of interactions with the soil minerals can be significant even compared to the rapid biological processes.

The observed variations in the ARQ values at the three calcareous soil sites provide direct evidence that the momentary $\mathrm{CO}_{2}$ flux is not representative of the rate of soil respiration. This conclusion is strengthened by the results obtained from the diffusion experiments, which showed that, in sterilized calcareous soils, the resulting $\mathrm{CO}_{2}$ concentrations were lower than expected if diffusion was the only active process. Several previous studies arrived at the same con-

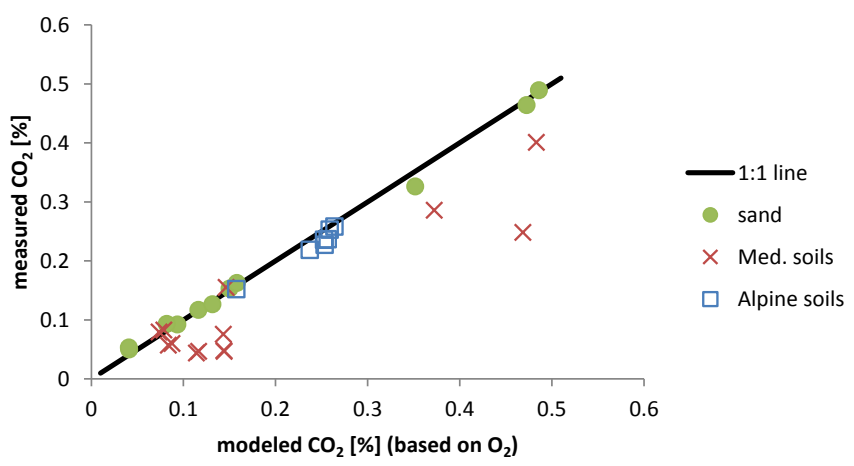

Figure 4. Diffusion in gamma-sterilized soils. For sand and alpine soils the measured $\mathrm{CO}_{2}$ agrees well with the values calculated from $\mathrm{O}_{2}$ concentration and the know diffusivity ratio, but this was not the case for Mediterranean soils, where measured $\mathrm{CO}_{2}$ concentrations were lower than expected from $\mathrm{O}_{2}$ measurements.

clusions by noting the mismatch between the measured and modeled $\mathrm{CO}_{2}$ fluxes or even by drawing on the results of geochemical modeling (Eshel et al., 2007; Hastings et al., 2005; Schlesinger et al., 2009; Serrano-Ortiz et al., 2010). However, to the best of our knowledge, this study provides the first confirmation and quantification of this effect by $\mathrm{O}_{2}$ monitoring in intact soil profiles.

A correct estimate of soil respiration should therefore account for the above-described processes and can be made by dividing the measured $\mathrm{CO}_{2}$ efflux by the efflux-weighted average soil profile ARQ. As an example, we applied the correction to the data collected at site 2 (Yatir forest), in which we measured detailed $\mathrm{CO}_{2}$ profiles and derived the diffusivity profile from the available soil properties and soil moisture data (Klein et al., 2013) after Moldrup et al. (2003). From the diffusivity and the $\mathrm{CO}_{2}$ concentration profiles, we calculated the expected net $\mathrm{CO}_{2}$ efflux from each layer. Note that this transport calculation assumes steady state (and hence ignores storage in the gas phase), neglects non-diffusive transport, which in some cases can be important (Maier et al., 2012), and is sensitive to the choice of the diffusion model (Pingintha et al., 2010). The resulting weighted average ARQ was 0.26 , which indicates that the biological respiration flux at this time of measurements was in fact 3.8 higher than the $\mathrm{CO}_{2}$ efflux.

The chemical interactions of respired $\mathrm{CO}_{2}$ with the soil solution and minerals can thus bias estimates of hourly and daily soil respiration measured by soil chambers or ecosystem respiration measured by eddy covariance flux. On these timescales, the soil $\mathrm{CO}_{2}$ efflux will not be a good indicator for the biological process of respiration at such sites. However, on longer timescales this effect is expected to be canceled out since, during soil drying, $\mathrm{CO}_{2}$ will be emitted out of the soil at a higher rate than the actual respiration flux, yielding high ARQ values, as noted at site 1 during the September experiment. This can be explained if we consider that dry- 
Table 2. Results of the soil incubation experiments with alpine forest soils. The soils were sieved to remove roots before incubation. The apparent respiratory quotient (ARQ) values declined with time since sampling and increase following the addition of sucrose, with good agreement between pair measurements. In order to calculate the dissolution-corrected ARQ the dissolved inorganic carbon in the soil solution was calculated, based on the $\mathrm{CO}_{2}$ partial pressure, the temperature, and the soil solution $\mathrm{pH}$.

\begin{tabular}{|c|c|c|c|c|c|c|c|}
\hline Depth & Site & $\begin{array}{r}\text { Start time } \\
\text { after sampling }(\mathrm{h})\end{array}$ & $\begin{array}{r}\text { Incubation } \\
\text { duration }(\mathrm{h})\end{array}$ & $\begin{array}{r}\mathrm{CO}_{2} \\
(\%)\end{array}$ & $\begin{array}{r}\mathrm{O}_{2} \\
(\%)\end{array}$ & ARQ & $\begin{array}{l}\text { Dissolution- } \\
\text { corrected ARQ }\end{array}$ \\
\hline $5-20 \mathrm{~cm}$ & 6 & 3.95 & 16.45 & 2.43 & 18.19 & 0.87 & 0.88 \\
\hline $5-20 \mathrm{~cm}$ & 6 & 3.95 & 32.78 & 3.85 & 16.49 & 0.85 & 0.87 \\
\hline $5-20 \mathrm{~cm}$ & 6 & 147.40 & 25.60 & 1.17 & 19.49 & 0.77 & 0.79 \\
\hline $5-20 \mathrm{~cm}$ & 6 & 147.40 & 44.80 & 2.08 & 18.35 & 0.78 & 0.80 \\
\hline $5-20 \mathrm{~cm}$ & 6 & $337+$ sucrose & 5.15 & 4.22 & 16.32 & 0.90 & 0.92 \\
\hline $5-20 \mathrm{~cm}$ & 6 & $337+$ sucrose & 22.37 & 15.21 & 2.37 & 0.82 & 0.83 \\
\hline $30-40 \mathrm{~cm}$ & 6 & 7.65 & 12.75 & 1.3 & 19.42 & 0.82 & 0.85 \\
\hline $30-40 \mathrm{~cm}$ & 6 & 7.65 & 29.08 & 2.3 & 18.15 & 0.81 & 0.83 \\
\hline $30-40 \mathrm{~cm}$ & 6 & 36.73 & 18.02 & 1.57 & 18.3 & 0.58 & 0.60 \\
\hline $30-40 \mathrm{~cm}$ & 6 & 36.73 & 45.62 & 2.86 & 16.36 & 0.61 & 0.63 \\
\hline $30-40 \mathrm{~cm}$ & 6 & 147.40 & 25.60 & 0.71 & 19.88 & 0.63 & 0.65 \\
\hline $30-40 \mathrm{~cm}$ & 6 & 147.40 & 44.80 & 1.16 & 19.22 & 0.65 & 0.67 \\
\hline $30-40 \mathrm{~cm}$ & 6 & $337+$ sucrose & 5.15 & 4.39 & 14.88 & 0.72 & 0.74 \\
\hline $30-40 \mathrm{~cm}$ & 6 & $337+$ sucrose & 22.37 & 14.78 & 2.18 & 0.79 & 0.81 \\
\hline $5-20 \mathrm{~cm}$ & 5 & 6.78 & 5.25 & 1.36 & 19.1 & 0.71 & 0.93 \\
\hline $5-20 \mathrm{~cm}$ & 5 & 6.78 & 12.75 & 2.48 & 17.36 & 0.68 & 0.89 \\
\hline $5-20 \mathrm{~cm}$ & 5 & 146.53 & 25.60 & 1.1 & 18.99 & 0.54 & 0.71 \\
\hline $5-20 \mathrm{~cm}$ & 5 & 146.53 & 44.80 & 2.01 & 17.54 & 0.58 & 0.76 \\
\hline $5-20 \mathrm{~cm}$ & 5 & $337+$ sucrose & 5.15 & 1.38 & 19.06 & 0.71 & 0.95 \\
\hline $5-20 \mathrm{~cm}$ & 5 & $337+$ sucrose & 22.37 & 7.63 & 12.72 & 0.92 & 1.24 \\
\hline
\end{tabular}

ing increases the soil solution DIC concentrations, and the respired $\mathrm{CO}_{2}$ that was consumed in dissolution Eqs. (1), (2) will be re-emitted during drying-associated reprecipitation of carbonate. Therefore, only DIC removal by drainage represents a permanent $\mathrm{CO}_{2}$ loss. However, such drainage is low in Mediterranean soils in general and in dry environments in particular. For example, at site 2, over $95 \%$ of the rainfall is accounted for by evapotranspiration (Raz-Yaseef et al., 2010).

The soil $\mathrm{CO}_{2}$ efflux measurements are usually reported and interpreted as soil respiration. Upscaling point measurements of particular dates to the entire year and entire region is usually done by fitting the efflux data to some temperature and soil moisture functions - assuming that the efflux is controlled only by the biological response of respiration. Based on the data we showed here, it seems important in calcareous soils to correct the $\mathrm{CO}_{2}$ efflux for nonbiological processes. Relatively fast and inexpensive $\mathrm{O}_{2}$ measurement were recently performed by Hilman and Angert (manuscript in preparation) and could facilitate similar studies in the future. We recommend that such future studies will also include ARQ measurements (by incubations chambers) of detached roots, in order to improve the method accuracy by directly estimating the root respiration ARQ at the study site. A previous study found the same RQ values for detached and intact roots: 0.80 to 0.95 (Lipp and Andersen, 2003); these are within the range we assumed here.

\subsection{Relationships between $\mathrm{CO}_{2}$ and $\mathrm{O}_{2}$ in low-pH soils}

The low ARQ values found in the in situ measurements in temperate forest (site 4; ARQ range: 0.58 to 0.70 ) and alpine forest (sites 5, 6; ARQ range: 0.23 to 0.96 ) were unexpected. At a soil pH of 4.3 and 4.9 (sites 4 and 6, respectively) almost no dissolved carbon in the soil solution can be in the form of bicarbonate or carbonate, and since the amount of carbon that can be dissolved in the form of $\mathrm{CO}_{2}(\mathrm{aq})$ is limited, the overall storage will be also small. As an example, with a $\mathrm{pH}$ of 4 and $\left[\mathrm{CO}_{2}\right]$ in soil air of $7000 \mathrm{ppm}$ only $1 \mathrm{~g} \mathrm{C}$ can be stored in the solution that is present in $1 \mathrm{~m}^{3}$ of soil (assuming that the solution occupies $25 \%$ of the volume). Since the summer respiration rates at these sites are on the order of a few $\mathrm{g} \mathrm{m}^{-2} \mathrm{~d}^{-1}$, the water entering the soil during a rain event cannot absorb $\mathrm{CO}_{2}$ for more than a few hours and thus will not remove a significant fraction of the respiratory production. As a result, the low ARQ in these soils is probably not driven by carbonate chemistry.

The non-geochemical control on the ARQ at the alpine sites was also demonstrated by the diffusion experiments in gamma-sterilized soils, in which the measured $\mathrm{CO}_{2}$ was as expected based on $\mathrm{O}_{2}$ measurements and the ratio of diffusivities of the two gases (0.76, same as used for the in situ profile ARQ calculations; Fig. 3). The observed low ARQ also occurs with no roots present, and, thus, processes within roots are not the sole driver of the ARQ $<0.9$. The DIC-corrected 
ARQ during incubation showed values as low as 0.60 , with an average of 0.78 . The ARQ values of the incubated soils also showed a decrease with time since sampling and an increase following the addition of sucrose. The incubation results indicate that the low ARQ values found in the in situ measurements in the acidic and neutral soils are real (e.g. not an artifact of the soil air profile sampling or modeling) and need to be explained.

A similar decrease in the incubated soil RQ with time (up to 100 days) since sampling was observed for the incubation of soils from grassland sites (Severinghaus, 1995). Low RQ values were reported for the incubation of acidic soils from Argentina (0.27-0.65; Aon et al., 2001) and from Germany (Dilly, $2001 ;<0.5$ for some soils). In the latter soils the RQ increased to $\sim 1.0$ immediately after glucose addition and reached $\sim 1.3$ with time. The low RQ noted in these soils (before glucose addition) was explained to be substrate related, and this hypothesis may also fit our incubation results from sites 4, 5, and 6. The decrease in the ARQ with time since soil sampling can be explained as the result of the exhaustion of labile sugars and organic acids supplied by the root exudates, while the resupply of sucrose supported the increase in the ARQ towards 1.0.

While the hypothesis of labile substrate exhaustion seems to fit the result of these experiments and of previous ones nicely, it leaves open the question of the non-labile substrates: what is their nature and why do they turn in a low RQ? Literature reports RQ values of 0.93 for average plant matter, 0.95 for wood, and 0.93 for soil humic acid and humins (Severinghaus, 1995). Values of 0.95-0.98 were measured (Randerson et al., 2006) for average plant RQs, whereas, when considering single plant chemical classes, the RQ was calculated as 0.88 for lignin, 0.95 for soluble phenolics, 1.0 for carbohydrates, 1.4 for organic acids, and 0.73 for lipids. Since only lipids are associated with a low RQ and since they are $\sim 10 \%$ of the soil carbon (Ziegler, 1989), one may suggest that lipids are the non-labile substrates responsible for the low soil RQ. However, since this would imply that almost $100 \%$ of the respiration in some of our incubation experiments derived from lipid substrates, we do not find this explanation very plausible.

The low ARQ values cannot be explained by nitrification (ammonium oxidation) either; this process lowers the RQ since it consumes oxygen, but it does not emit $\mathrm{CO}_{2}$. However, the elemental-composition-based RQ values cited above already account for the content of reduced nitrogen and hence for nitrification. Moreover, it does not seem likely that this process will become more important with incubation time since ammonium stocks will probably be depleted.

Thus, we suggest that the oxidation of $\mathrm{Fe}^{2+}$ (and another reduced species) could be the most likely process that can explain the low RQ values in noncalcareous soils given that it consumes $\mathrm{O}_{2}$ but does not release $\mathrm{CO}_{2}$. While the soils we studied were well-aerated, it was previously shown that, even in such soils, anoxic microsites might be present inside soil aggregates (von Fischer and Hedin, 2002). The $\mathrm{Fe}^{2+}$ can be formed inside the soil aggregates when the soil is wet (or when respiration rates are very high, as is the case after sucrose addition), and as the soil dries (or sucrose stock depletes) oxygen can diffuse into the soil aggregate and react with the $\mathrm{Fe}^{2+}$. With this explanation, the RQ will be above 1.0 when the aggregates are anoxic since $\mathrm{CO}_{2}$ will be produced but $\mathrm{Fe}^{2+}$ and not $\mathrm{O}_{2}$ will be the oxygen acceptor. Since the soil diffusivity in this step is low, there will be limited gas exchange between the aggregate and its surroundings, and this high RQ value will be hard to measure. As the soil dries, the RQ will drop below 1.0, since oxygen will be consumed by $\mathrm{Fe}^{2+}$ with no $\mathrm{CO}_{2}$ production. Indeed, recent soil incubations that we undertook showed a decrease in $\mathrm{Fe}^{2+}$ and a drop in the ARQ during soil drying. In previous studies (Hall et al., 2013; Hall and Silver, 2013), highland soils with a mean bulk soil-air $\mathrm{O}_{2}$ of $19 \%$ were found to have over $6 \mathrm{mg} \mathrm{g}^{-1}$ (soil) of $\mathrm{Fe}^{2+}$, which can sustain oxidation over a few days at the rates we measured in our soil incubation experiments. On average in the long term, the RQ should match the value expected from the elemental composition of plants to keep ecosystem stoichiometry balanced. However, such $\mathrm{Fe}$ redox reactions provide another mechanism by which the instantaneous respiration rate is decoupled from the gas fluxes.

The ratio between oxygen consumption to $\mathrm{CO}_{2}$ release (the OR, the inverse of the RQ) in soil respiration is an important parameter in estimates of global carbon sinks from atmospheric $\mathrm{O}_{2}$ measurements (Keeling et al., 1996). Small deviations in the global soil respiration OR from the assumed value, can introduce considerable error to such estimates (Randerson et al., 2006). In this study we report large deviations measured in the RQ (and hence the OR), but such effects might be temporal or local fluctuations and cannot be used to infer the global annual average value before a more systematic measurement program is applied.

\section{Conclusions}

Our results demonstrate that, in contrast to the common assumption, soil ARQ (and RQ) values are rarely 1.0 and often deviate from this value considerably. In calcareous soils this is most likely due to chemical reactions with the soil solution and minerals, which need to be accounted for during attempts to estimate the biological $\mathrm{CO}_{2}$ efflux on short timescales, such as weekly to seasonal ones. This can be done by introducing measurements of the weighted average ARQ into the soil profile, as done here, and then dividing the measured $\mathrm{CO}_{2}$ efflux by the observed ARQ. Such measurements become less important on annual and longer timescales when the effects of $\mathrm{CO}_{2}$ storage and release are probably canceled out. In acidic and neutral soils, the variations in the RQ are probably related to substrates and processes that are not well understood at present and warrant further research. 
Acknowledgements. We thank Kathleen Savage for assistance at the Harvard Forest field site and for the soil $\mathrm{CO}_{2}$ analyses there. This research was supported by a grant from the German-Israeli Foundation (GIF) for Scientific Research no. 1139/2011. This is Scientific Contribution number 5011 of the University of Maryland Center for Environmental Science Appalachian Laboratory.

Edited by: E. Pendall

\section{References}

Amthor, J. S., Koch, G. W., Willms, J. R., and Layzell, D. B.: Leaf $\mathrm{O}_{2}$ uptake in the dark is independent of coincident $\mathrm{CO}_{2}$ partial pressure, J. Exp. Bot., 52, 2235-2238, 2001.

Angert, A. and Sherer, Y.: Determining the relationship between tree-stem respiration and $\mathrm{CO}_{2}$ efflux by $\mathrm{dO}_{2} / \mathrm{Ar}$ measurements, Rapid Commun. Mass Sp., 25, 1752-1756, 2011.

Angert, A., Luz, B., and Yakir, D.: Fractionation of oxygen isotopes by respiration and diffusion in soils and its implications for the isotopic composition of atmospheric $\mathrm{O}_{2}$, Global Biogeochem. Cy., 15, 871-881, 2001.

Angert, A., Muhr, J., Negron Juarez, R., Alegria Muñoz, W., Kraemer, G., Ramirez Santillan, J., Barkan, E., Mazeh, S., Chambers, J. Q., and Trumbore, S. E.: Internal respiration of Amazon tree stems greatly exceeds external $\mathrm{CO}_{2}$ efflux, Biogeosciences, 9, 4979-4991, doi:10.5194/bg-9-4979-2012, 2012.

Aon, M. A., Sarena, D. E., Burgos, J. L., and Cortassa, S.: Interaction between gas exchange rates, physical and microbiological properties in soils recently subjected to agriculture, Soil Till. Res., 60, 163-171, 2001.

Aubrey, D. P. and Teskey, R. O.: Root-derived $\mathrm{CO}_{2}$ efflux via xylem stream rivals soil $\mathrm{CO}_{2}$ efflux, New Phytol., 184, 35-40, 2009.

Barford, C. C., Wofsy, S. C., Goulden, M. L., Munger, J. W., Pyle, E. H., Urbanski, S. P., Hutyra, L., Saleska, S. R., Fitzjarrald, D., and Moore, K.: Factors controlling long- and short-term sequestration of atmospheric $\mathrm{CO}_{2}$ in a mid-latitude forest, Science, 294, 1688-1691, 2001.

Benavente, J., Vadillo, I., Carrasco, F., Soler, A., Linan, C., and Moral, F.: Air carbon dioxide contents in the vadose zone of a mediterranean karst, Vadose Zone J., 9, 126-136, 2010.

Bloemen, J., McGuire, M. A., Aubrey, D. P., Teskey, R. O., and Steppe, K.: Transport of root-respired $\mathrm{CO}_{2}$ via the transpiration stream affects aboveground carbon assimilation and $\mathrm{CO}_{2}$ efflux in trees, New Phytol., 197, 555-565, 2012.

Bond-Lamberty, B. and Thomson, A.: Temperature-associated increases in the global soil respiration record, Nature, 464, 579$582,2010$.

Carmi, I., Yakir, D., Yechieli, Y., Kronfeld, J., and Stiller, M.: Variations in soil $\mathrm{CO}_{2}$ concentrations and isotopic values in a semiarid region due to biotic and abiotic processes in the unsaturated zone, Radiocarbon, 55, 932-942, 2013.

Cuezva, S., Fernandez-Cortes, A., Benavente, D., Serrano-Ortiz, R., Kowalski, A. S., and Sanchez-Moral, S.: Short-term $\mathrm{CO}_{2}(\mathrm{~g})$ exchange between a shallow karstic cavity and the external atmosphere during summer: Role of the surface soil layer, Atmos. Environ., 45, 1418-1427, 2011.

Davey, P. A., Hunt, S., Hymus, G. J., DeLucia, E. H., Drake, B. G., Karnosky, D. F., and Long, S. P.: Respiratory oxygen uptake is not decreased by an instantaneous elevation of $\left[\mathrm{CO}_{2}\right]$, but is increased with long-term growth in the field at elevated $\left[\mathrm{CO}_{2}\right]$, Plant Physiol., 134, 520-527, 2004.

Davidson, E. A. and Trumbore, S. E.: Gas diffusivity and production of $\mathrm{CO}_{2}$ in deep soils of the eastern Amazon, Tellus B, 47, 550 565,1995 .

Davidson, E. A., Belk, E., and Boone, R. D.: Soil water content and temperature as independent or confounded factors controlling soil respiration in a temperate mixed hardwood forest, Glob. Change Biol., 4, 217-227, 1998.

Davidson, E. A., Savage, K., Verchot, L. V., and Navarro, R.: Minimizing artifacts and biases in chamber-based measurements of soil respiration, Agr. Forest Meteorol., 113, 21-37, 2002.

Dilly, O.: Microbial respiratory quotient during basal metabolism and after glucose amendment in soils and litter, Soil Biol Biochem., 33, 117-127, 2001.

Emmerich, W. E.: Carbon dioxide fluxes in a semiarid environment with high carbonate soils, Agr. Forest Meteorol., 116, 91-102, 2003.

Eshel, G., Fine, P., and Singer, M. J.: Total soil carbon and water quality: An implication for carbon sequestration, Soil Sci. Soc. Am. J., 71, 397-405, 2007.

Hall, S. J., and Silver, W. L.: Iron oxidation stimulates organic matter decomposition in humid tropical forest soils, Glob. Change Biol., 19, 2804-2813, 2013.

Hall, S. J., McDowell, W. H., and Silver, W. L.: When wet gets wetter: Decoupling of moisture, redox biogeochemistry, and greenhouse gas fluxes in a humid tropical forest soil, Ecosystems, 16, 576-589, 2013.

Hastings, S. J., Oechel, W. C., and Muhlia-Melo, A.: Diurnal, seasonal and annual variation in the net ecosystem $\mathrm{CO}_{2}$ exchange of a desert shrub community (Sarcocaulescent) in Baja California, Mexico, Glob. Change Biol., 11, 927-939, 2005.

Hesterberg, R., and Siegenthaler, U.: Production and Stable Isotopic Composition of $\mathrm{CO}_{2}$ in a Soil near Bern, Switzerland, Tellus B, 43, 197-205, 1991.

Hockaday, W. C., Masiello, C. A., Randerson, J. T., Smernik, R. J., Baldock, J. A., Chadwick, O. A., and Harden, J. W.: Measurement of soil carbon oxidation state and oxidative ratio by ${ }^{13} \mathrm{C}$ nuclear magnetic resonance, J. Geophys. Res.-Biogeo., 114 G02014, doi:10.1029/2008jg000803, 2009.

Ishidoya, S., Murayama, S., Takamura, C., Kondo, H., Saigusa, N., Goto, D., Morimoto, S., Aoki, N., Aoki, S., and Nakazawa, T.: $\mathrm{O}_{2}: \mathrm{CO}_{2}$ exchange ratios observed in a cool temperate deciduous forest ecosystem of central Japan, Tellus B, 65, 21120 doi:10.3402/tellusb.v65i0.21120, 2013.

Jury, W. A., Gardner, W. R., and Gardner, W. H.: Soil Physics, Wiley, 1991.

Keeling, R. F., Piper, S. C., and Heimann, M.: Global and hemispheric $\mathrm{CO}_{2}$ sinks deduced from changes in atmospheric $\mathrm{O}_{2}$ concentration, Nature, 381, 218-221, 1996.

Klein, T., Hemming, D., Lin, T. B., Grunzweig, J. M., Maseyk, K., Rotenberg, E., and Yakir, D.: Association between tree-ring and needle delta C-13 and leaf gas exchange in Pinus halepensis under semi-arid conditions, Oecologia, 144, 45-54, 2005.

Klein, T., Shpringer, I., Fikler, B., Elbaz, G., Cohen, S., and Yakir, D.: Relationships between stomatal regulation, water-use, and water-use efficiency of two coexisting key Mediterranean tree species, For. Ecol. Manage., 302, 34-42, 2013. 
Kowalski, A. S., Serrano-Ortiz, P., Janssens, I. A., Sanchez-Moral, S., Cuezva, S., Domingo, F., Were, A., and Alados-Arboledas, L.: Can flux tower research neglect geochemical $\mathrm{CO}_{2}$ exchange?, Agr. Forest Meteorol., 148, 1045-1054, 2008.

Lambers, H., Chapin, F. S., III, and Pons, T. L.: Plant Physiological Ecology, 2nd ed., Springer, 610 pp., 2008.

Lipp, C. C. and Andersen, C. P.: Role of carbohydrate supply in white and brown root respiration of ponderosa pine, New Phytol., 160, 523-531, 2003.

Ma, J., Wang, Z. Y., Stevenson, B. A., Zheng, X. J., and Li, Y.: An inorganic $\mathrm{CO}_{2}$ diffusion and dissolution process explains negative $\mathrm{CO}_{2}$ fluxes in saline/alkaline soils, Sci. Rep., 3, 2025, doi:10.1038/srep02025, 2013.

Maier, M., Schack-Kirchner, H., Aubinet, M., Goffin, S., Longdoz, B., and Parent, F.: Turbulence effect on gas transport in three contrasting forest soils, Soil Sci. Soc. Am. J., 76, 1518-1528, 2012.

Masiello, C. A., Gallagher, M. E., Randerson, J. T., Deco, R. M., and Chadwick, O. A.: Evaluating two experimental approaches for measuring ecosystem carbon oxidation state and oxidative ratio, J. Geophys. Res.-Biogeo., 113, G03010, doi:10.1029/2007jg000534, 2008.

Massman, W. J.: A review of the molecular diffusivities of $\mathrm{H}_{2} \mathrm{O}$, $\mathrm{CO}_{2}, \mathrm{CH}_{4}, \mathrm{CO}, \mathrm{O}_{3}, \mathrm{SO}_{2}, \mathrm{NH}_{3}, \mathrm{~N}_{2} \mathrm{O}, \mathrm{NO}$, and $\mathrm{NO}_{2}$ in air, $\mathrm{O}_{2}$ and $\mathrm{N}_{2}$ near STP, Atmos. Environ., 32, 1111-1127, 1998.

Millington, R. J. and Shearer, R. C.: Diffusion in aggregated porous media, Soil Sci., 111, 372-378, 1971.

Moldrup, P., Olesen, T., Komatsu, T., Yoshikawa, S., Schjonning, P., and Rolston, D. E.: Modeling diffusion and reaction in soils: $\mathrm{X}$. A unifying model for solute and gas diffusivity in unsaturated soil, Soil Sci., 168, 321-337, 2003.

Pingintha, N., Leclerc, M. Y., Beasley Jr, J., Zhang, G., and Senthong, $\mathrm{C}$.: Assessment of the soil $\mathrm{CO}_{2}$ gradient method for soil $\mathrm{CO}_{2}$ efflux measurements: comparison of six models in the calculation of the relative gas diffusion coefficient, Tellus B, 62, 47-58, 2010.

Raich, J. W. and Schlesinger, W. H.: The global carbon dioxide flux in soil respiration and its relationship to vegetation and climate, Tellus B, 44, 81-99, 1992.

Raich, J. W. and Potter, C. S.: Global patterns of carbon dioxide emissions from soils, Global Biogeochem. Cy., 9, 23-36, 1995.

Randerson, J. T., Masiello, C. A., Still, C. J., Rahn, T., Poorter, H., and Field, C. B.: Is carbon within the global terrestrial biosphere becoming more oxidized? Implications for trends in atmospheric $\mathrm{O}_{2}$, Glob. Change Biol., 12, 260-271, 2006.

Raz-Yaseef, N., Yakir, D., Rotenberg, E., Schiller, G., and Cohen, S.: Ecohydrology of a semi-arid forest: partitioning among water balance components and its implications for predicted precipitation changes, Ecohydrology, 3, 143-154, 2010.

Rodeghiero, M. and Cescatti, A.: Main determinants of forest soil respiration along an elevation/temperature gradient in the Italian Alps, Glob. Change Biol., 11, 1024-1041, 2005.
Roland, M., Serrano-Ortiz, P., Kowalski, A. S., Goddéris, Y., Sánchez-Cañete, E. P., Ciais, P., Domingo, F., Cuezva, S., Sanchez-Moral, S., Longdoz, B., Yakir, D., Van Grieken, R., Schott, J., Cardell, C., and Janssens, I. A.: Atmospheric turbulence triggers pronounced diel pattern in karst carbonate geochemistry, Biogeosciences, 10, 5009—5017, doi:10.5194/bg-105009-2013, 2013.

Rotenberg, E. and Yakir, D.: Contribution of semi-arid forests to the climate system, Science, 327, 451-454, 2010.

Schlesinger, W. H., Belnap, J., and Marion, G.: On carbon sequestration in desert ecosystems, Glob. Change Biol., 15, 1488-1490, 2009.

Seibt, U., Brand, W. A., Heimann, M., Lloyd, J., Severinghaus, J. P., and Wingate, L.: Observations of $\mathrm{O}_{2}: \mathrm{CO}_{2}$ exchange ratios during ecosystem gas exchange, Global Biogeochem. Cy., 18, GB4024, doi:10.1029/2004gb002242, 2004.

Serrano-Ortiz, P., Roland, M., Sanchez-Moral, S., Janssens, I. A., Domingo, F., Godderis, Y., and Kowalski, A. S.: Hidden, abiotic $\mathrm{CO}_{2}$ flows and gaseous reservoirs in the terrestrial carbon cycle: Review and perspectives, Agr. Forest Meteorol., 150, 321-329, 2010.

Severinghaus, J. P.: Studies of the Terrestrial $\mathrm{O}_{2}$ and Carbon Cycles in Sand Dune Gases and in Biospere 2, Columbia University, 1995.

Stern, L., Baisden, W. T., and Amundson, R.: Processes controlling the oxygen isotope ratio of soil $\mathrm{CO}$ (sub 2) ; analytic and numerical modeling, Geochim. Cosmochim. Ac., 63, 799-814, 1999.

Stevenson, B. A. and Verburg, P. S. J.: Effluxed $\mathrm{CO}_{2}-\mathrm{C}-13$ from sterilized and unsterilized treatments of a calcareous soil, Soil Biol. Biochem., 38, 1727-1733, 2006.

Stumm, W. and Morgan, J. J.: Aquatic Chemistry: Chemical Equilibria and Rates in Natural Waters, John Wiley \& Sons, 2012.

Tamir, G., Shenker, M., Heller, H., Bloom, P. R., Fine, P., and BarTal, A.: Can soil carbonate dissolution lead to overestimation of soil respiration?, Soil Sci. Soc. Am. J., 75, 1414-1422, 2011.

Vargas, R., Carbone, M., Reichstein, M., and Baldocchi, D.: Frontiers and challenges in soil respiration research: from measurements to model-data integration, Biogeochemistry, 102, 1-13, 2011.

von Fischer, J. C. and Hedin, L. O.: Separating methane production and consumption with a field-based isotope pool dilution technique, Global Biogeochem. Cy., 16, 8-1-8-13, doi:10.1029/2001gb001448, 2002.

Wang, W. F., Chen, X., Luo, G. P., and Li, L. H.: Modeling the contribution of abiotic exchange to $\mathrm{CO}_{2}$ flux in alkaline soils of arid areas, J. Arid Land, 6, 27-36, 2014.

Ziegler, F.: Changes of lipid content and lipid composition in forest humus layers derived from Norway spruce, Soil Biol. Biochem., 21, 237-243, 1989. 